\title{
KUALITAS PELAYANAN IZIN MENDIRIKAN BANGUNAN (IMB) PADA BADAN PELAYANAN PERIZINAN TERPADU (BPPT) KOTA BANDUNG
}

\author{
Oleh
}

\author{
Irvan Arif Kurniawan \\ Prodi Ilmu Administrasi Negara \\ Universitas Islam Syekh-Yusuf \\ Email : iakurniawan@unis.ac.id
}

\begin{abstract}
Abstrak
Badan Pelayanan Perizinan Terpadu (BPPT) Kota Bandung merupakan Lembaga yang menyelenggarakan pelayanan perizinan satu pintu khususnya pelayanan izin mendirikan bangunan (IMB) di Kota Bandung. Pelayanan IMB di BPPT Kota Bandung dilakukan secara terpadu dengan melibatkan dinas terkait. Pelayanan IMB di Kota Bandung merupakan pelayanan yang paling banyak diajukan oleh masyarakat. Oleh karena itu didalam pelaksanaanya perlu memperhatikan kualitas pelayanan. Kualitas pelayanan publik dapat dilihat dari lima dimensi SERVQUAL (Service Quality) yaitu dimensi tangible, dimensi reliability, dimensi responsiveness, dimensi assurance, dan dimensi emphaty. Metode deskriptif dipilih untuk menganalisis kualitas pelayanan IMB di BPPT Kota Bandung dari lima dimensi SERVQUAL. Hasil dari penelitian ini menunjukan dimensi tangible, dimenasi reliability, dimensi responsiveness, dimensi assurance, dan dimensi emphaty telah diterapkan dalam pelayanan IMB. Dari kelima dimensi tersebut perlu didukung oleh teknologi informasi yang memadai agar pelayanan izin mendirikan bangunan dapat meningkatkan kualitas pelayanan publik, khususnya pada dimenasi responsiveness.
\end{abstract}

Kata kunci : Kualitas Pelayanan, Izin Mendirikan Bangunan, Tangible, Reliability, Responsiveness, Assurance, dan Empahty.

\begin{abstract}
The Bandung City Integrated Licensing Service Agency (BPPT) is an institution that provides one-stop licensing services, especially building construction permit (IMB) services in Bandung City. IMB services at BPPT City Bandung are carried out in an integrated manner by involving related agencies. IMB services in the city of Bandung are the services most proposed by the public. Therefore, in its implementation, it is necessary to pay attention to the quality of service. The quality of public services can be seen from the five dimensions of SERVQUAL (Service Quality), namely the tangible dimension, the reliability dimension, the responsiveness dimension, the assurance dimension, and the
\end{abstract}


empathy dimension. The descriptive method was chosen to analyze the quality of IMB services at BPPT Bandung City from the five dimensions of SERVQUAL. The results of this study indicate that the tangible dimensions, dimension reliability, dimensional responsiveness, dimensional assurance, and empathy dimensions have been implemented in IMB services. Of the five dimensions, it is necessary to support adequate information technology so that building services can improve the quality of public services, especially in the dimension of responsiveness.

Keyword : Service Quality, Building permit, Tangible, Reliability, Responsiveness, Assurance, and, Empahty.

\section{A. PENDAHULUAN}

Keberadaan layanan terpadu merupakan solusi yang dapat ditawarkan dalam upaya meningkatkan kualitas layanan publik. Selain itu pelayanan terpadu satu pintu dapat menjadi faktor pendorong dalam menarik investor untuk berinvestasi. Pelayanan Terpadu Satu Pintu (PTSP) merupakan penyelenggara kegiatan perizinan dan non perizinan yang ada disetiap kabupaten/kota dan provinsi mendapatkan wewenang dari instansi yang memiliki wewenang dalam proses perizinan mulai dari tahap permohonan hingga tahap terbitnya dokuman yang diproses dalam satu tempat yang sama. ${ }^{1}$ Saat ini telah banyak daerah kabupaten/kota yang mendirikan layanan terpadu, baik yang berfokus pada layanan Perizinan dan atau non perizinan.

Diterbitkannya Permendagri No 24 tahun 2006 tentang Pedoman Pendirian Pelayanan Terpadu Satu Pintu (PTSP) sebagai penjabaran Inpres No 3 tahun 2006 merupakan bagian dari upaya mencapai peningkatan kualitas layanan publik. ${ }^{2}$ Telah disadari pelayanan publik yang selama ini dikenal oleh masyarakat adalah pelayanan yang berbelit-belit. Amat sulit untuk memahami pelayanan yang diselenggarakan oleh birokrasi publik.

Ada berbagai macam jenis pelayanan publik yang diberikan kepada masyarakat, salah satunya pelayanan izin mendirikan bangunan (IMB). Pelayanan izin mendirikan bangunan atau IMB, merupakan pelayanan perizinan yang paling banyak diajukan oleh masyarakat. Jumlah pelayanan IMB pada tahun 2014 di BPPT Kota Bandung mencapai 4580 ajuan $^{3}$. Mayoritas dari jumlah ajuan izin tersebut digunakan untuk keperluan pembangunan rumah tinggal. Berdasarkan hasil dari obeservasi, kelengkapan surat keterangan IMB juga dijadikan sebagai salah satu syarat pengajuan pinjaman kredit ke bank.

Berdasarkan data yang diperoleh peneliti dari lapangan sebanyak $74 \%$ pengajuan IMB untuk keperluan rumah tinggal. Sisanya IMB digunakan untuk

\footnotetext{
${ }^{1}$ Undang-Undang No 25 Tahun 2007 tentang Penanaman Modal

2 Peraturan Menteri Dalam Negeri Nomor 24 Tahun 2006 Tentang Pedoman

Penyelenggaraan Pelayanan Terpadu Satu Pintu.

${ }^{3}$ Hasil olahan data peneliti di BPPT Kota Bandung (per 21 Januari 2015)
} 
keperluan kantor $1 \%$, toko $11 \%$, rumah tinggal toko $8 \%$, rumah tinggal kantor $3 \%$, pabrik $1 \%$, rubah fungsi bangunan $1 \%$ dan untuk keperluan UMKM $1 \%$. Data tersebut dapat dilihat pada gambar diagram berikut ini :

\section{Diagram 1.1 Persentase Jumlah Kegunaan IMB}

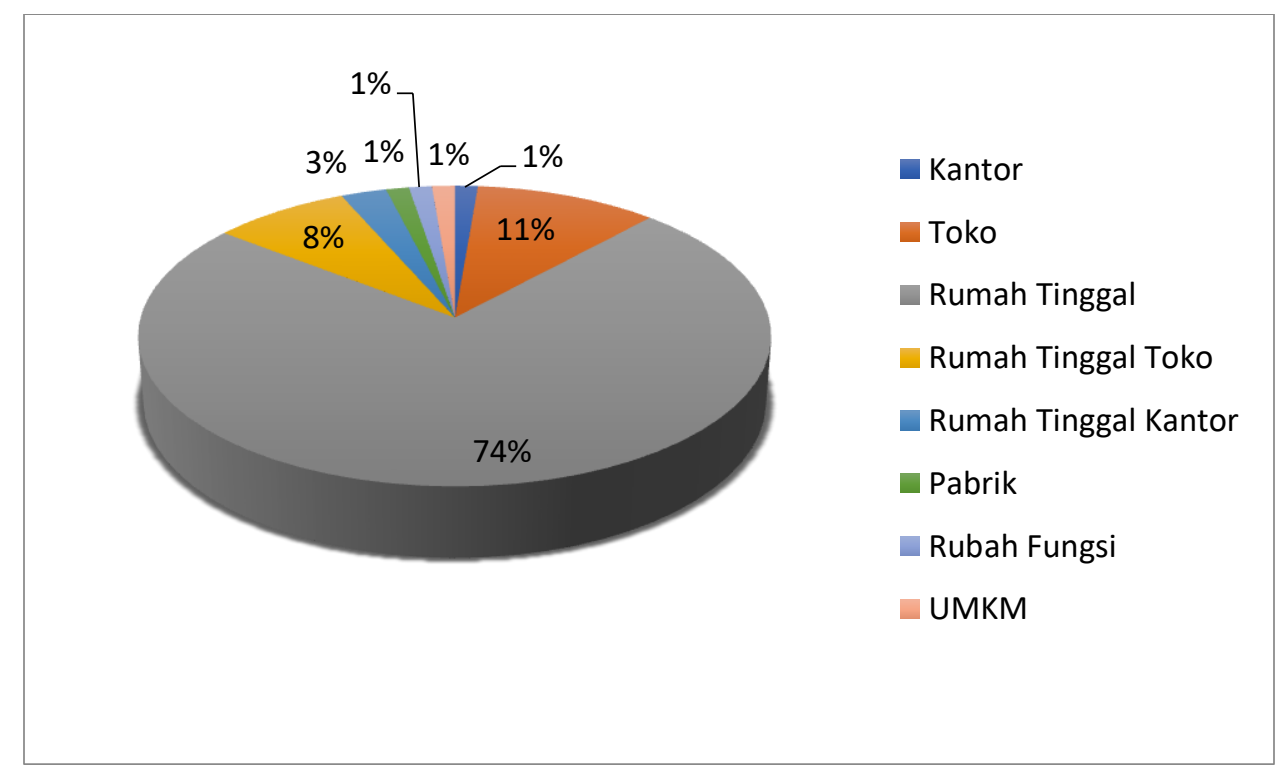

Sumber : Hasil olahan peneliti tahun 2015

Pelayanan IMB di BPPT Kota Bandung yang dilakukan melalui pelayanan terpadu satu pintu (PTSP) hanya bersifat administratif. Ini artinya pelayanan IMB dapat dilakukan di BPPT Kota Bandung apabila seluruh berkas telah memenuhi persyaratan. Setelah memenuhi persyaratan yang diminta maka proses pelayanan IMB akan dilakukan selama 19 - 60 hari kerja ${ }^{4}$. Didalam proses pelayanan IMB, BPPT Kota Bandung melakukan koordinasi dengan dinas teknis terkait seperti Dinas Tata Ruang dan Cipta Karya, Bappeda, dan Badan Lingkungan Hidup. Didalam proses pelayanan IMB, memerlukan berbagai surat rekomendasi dari dinas-dinas teknis tersebut. Dari uraian diatas, maka peneliti tertarik untuk mengkaji kualitas pelayanan perizinan IMB di Badan Pelayanan Terpadu Satu Pintu (BPPT) Kota Bandung.

Berdasarkan hasil penelitian disertasi dari William Agustinus A. (2012) yang berjudul Implementasi Kebijakan Pemberian Izin Mendirikan Bangunan oleh Badan Pelayanan Perizinan Terpadu Kota Manado. ${ }^{5}$ Penelitian ini bertujuan untuk menganalisis implentasi kebijakan pemberian izin mendirikan bangunan yang untuk selanjutnya diharapkan memperoleh konsep baru bagi

\footnotetext{
${ }^{4}$ http://www.boss.or.id/index.php?option=com content\&view=article\&id=87\&ltemid=114

5 Areros, William Agustinus. 2012. Implementasi Kebijakan Pemberian Izin Mendirikan Bangunan oleh Badan Pelayanan Perizinan Terpadu Kota Bandung: Universitas Padjadjaran.
} 
pengembangan ilmu administrasi publik. ${ }^{6}$ Hasil penelitian ini menemukan bahwa implementasi kebijakan pemberian izin mendirikan bangunan oleh BPPT Kota Manado belum berjalan sebagaimana kebijakan secara efektif bila dilihat dari sisi organisasi, interpretasi dan aplikasi. ${ }^{7}$ Belum berjalannya implementasi kebijakan diakibatkan oleh keterbatasan sumber daya manusia dan fasilitas fisik yang dimiliki, tidak terlaksananya fungsi pengawasan di lapangan terhadap bangunan yang tidak memiliki IMB, serta masih adanya masyarakat yang mengurus IMB setalah bangunannya selesai didirikan dan tidak berjalannya fungsi koordinasi antar instansi terkait. ${ }^{8}$

\section{B. TINJAUAN PUSTAKA}

\section{Konsep Kualitas Pelayanan Publik}

Konsep kualitas pelayanan dapat dipahami pula melalui "consumer behavior" (perilaku konsumen) yaitu suatu prilaku yang dimainkan oleh konsumen dalam mencari, membeli, menggunkan dan mengevaluasi suatu produk pelayanan yang diharapkan dapat memuaskan kebutuhannya (Schiffman-Kanuk, 1997:7). ${ }^{9}$ Keputusan-keputusan konsumen untuk mengkonsumsi atau tidak mengkonsumsi suatu barang/jasa dipengaruhi oleh berbagai faktor antara lain adalah persepsinya terhadap kualitas pelayanan. Pengertian tentang kualitas pelayanan terfokus pada upaya pemenuhan kebutuhan dan keinginan pengguna layanan serta ketetapan penyampaiannya untuk mengimbangi harapan pengguna layanan. Kemudian Heizer dan Render (1993:734), menambahkan kualitas adalah derajat sejauh mana produk memenuhi spesifikasi-spesifikasinya. Kualitas pada dasarnya terkait dengan pelayanan yang terbaik, yaitu suatu sikap atau cara karyawan dalam melayani pelanggan atau masyarakat secara memuaskan.

Kualitas pelayanan merupakan suatu kondisi dinamis yang dapat berpengaruh dengan produk, jasa, manusia, proses dan lingkungan atau melebihi harapan (Tjiptono, 1990:14). Dari definisi tersebut dapat dikatakan kualitas pelayanan sebagai upaya untuk memenuhi kebutuhan dan keinginan pelanggan dalam mengimbangi harapan pelanggan. ${ }^{10}$

Parasuraman dkk. (1988:21) mengemukakan bahwa didalam mengukur kualitas pelayanan publik terdapat lima dimenasi kualitas pelayanan publik

\footnotetext{
${ }^{6}$ Ibid

${ }^{7} \mathrm{lbid}$

${ }^{8}$ Ibid

${ }^{9}$ Schiffman-Kanuk 1997. Consumer Behaviour. Fifth Edition. New York, USA. Prentice hall. International Edition. Inc.

${ }^{10}$ Tjiptono, Fandi.1990. Delivering Quality Service: Balancing Customer Preception and Expectation. New York: The Free Press.
} 
yang disebut SERVQUAL (Service Quality). Kelima dimensi yang disebut SERVQUAL terdiri dari :11

1) Tangibles (bukti langsung), meliputi fasilitas fisik, perlengkapan, penampilan pegawai, dan sarana komunikasi.

2) Reliability (kehandalan), kemampuan memberikan pelayanan yang dijanjikan dengan cepat dan memuaskan.

3) Responsiveness (daya tangkap), keinginan para staf untuk membantu pelanggan dan memberikan pelayanan dengan tanggap.

4) Assurance (jaminan), kemampuan, kesopanan, dan para staf dapat dipercaya, dan percaya diri.

5) Emphaty (empati), kemudahan dalam melakukan hubungan, perhatian individu dalam memahami kebutuhan pelanggan.

(Parasuraman dkk, 1988:21)

\section{Izin Mendirikan Bangunan (IMB)}

Izin Mendirikan Bangunan (IMB) merupakan suatu produk hukum yang berisi persetujuan atau perizinan yang dikerluarkan oleh kepala daerah setempat kepada pemilik bangunan yang ingin membangun, merobohkan, menambah/mengurangi luas, atau merenovasi suatu bangunan 12. Setiap bangunan gedung harus memenuhi persyaratan administratif dan persyaratan teknis sesuai dengan fungsi bangunan gedung. Setiap bangunan gedung harus memenuhi persyaratan administratif yang meliputi :

a) Status hak atas tanah, dan/atau izin pemanfaatan dari pemegang hak tanah;

b) Status kepemilikan bangunan gedung; dan

c) Izin mendirikan bangunan gedung

\section{Pengertian Badan}

Didalam Peraturan Menteri Dalam Negeri Nomor 20 Tahun 2008 tentang Pedoman Organisasi dan Tatakerja Unit Pelayanan Perizinan Terpadu di Daerah pasal 2 ayat 1 disebutkan, bahwa dalam rangka meningkatkan pelayanan masyarakat di bidang perijinan dibentuk unit pelayanan perijinan terpadu dengan sebutan badan atau kantor. Badan atau Kantor tersebut kedudukannya berada dibawah kepala daerah melalui sekretaris daerah seperti yang dijelaskan didalam pasal 3 ayat 1. Didalam Peraturan Menteri Dalam Negeri Nomor 20 Tahun 2008 pasal 7 ayat 1 disebutkan, bahwa : Besaran organisasi Badan

\footnotetext{
${ }^{11}$ Parasuraman, A. Valerie A. Zeithmal, and Leonard L. Berry. 1985. A Conceptual Model of Service Quality and its Implications for Future Research. Dalam Journal of Marketing. Vol 49 (Fall 1985), 41-50.

${ }^{12}$ https://id.wikipedia.org/wiki//zin_Mendirikan_Bangunan
} 
dan/atau Kantor ditetapkan berdasarkan klasifikasi besaran organisasi perangkat daerah ${ }^{13}$.

Badan merupakan unsur penyelenggaraan pemerintah daerah. Badan dipimpin oleh seorang Kepala Badan, dan Kepala Badan dalam menjalankan tugasnya berkedudukan di bawah dan tanggung jawab kepada Gubernur (atau Bupati/Walikota) melalui Sekretaris Daerah. Pada Badan daerah dapat dibentuk Unit Pelakasana Teknis tertentu untuk melaksanakan kegiatan teknis operasional/dan atau penunjang ${ }^{14}$.

\section{METODE PENELITIAN}

Penelitian ini membahas mengenai kualitas pelayanan izin mendirikan bangunan di Badan Pelayanan Terpadu Satu Pintu (BPPT) Kota Bandung. Penelitian ini menggunakan metode penelitian kualitatif. Di dalam penelitian ini, penulis mendeskrisipkan kualitas pelayanan izin mendirikan bangunan (IMB) yang dilaksanakan oleh BPPT Kota Bandung secara deskriptif. Metode penelitian deskriptif ini menggambarkan atau mendeskripsikan sejumlah fakta dilapangan yang berkaitan dengan kualitas pelayanan Izin Mendirikan Bangunan (IMB) di BPPT Kota Bandung. ${ }^{15}$

\section{PEMBAHASAN}

Hasil penelitian ini menggambarkan kualitas pelayanan Izin Mendirikan Bangunan (IMB) Kota Bandung berdasarkan 5 (lima) dimensi yang terdiri dari, dimensi tangible, dimensi reliability, dimensi responsiveness, dimensi assurance, dan dimensi emphaty. Masing-masing dimensi kualitas pelayanan publik ini memiliki indiaktor yang bervariasi. Kualitas pelayanan IMB di BPPT Kota Bandung akan di gambarkan berdasarkan indikator yang digunakan secara kualitatif.

\section{Dimensi Tangible (Bukti Fisik)}

Kenyamanan fisik gedung merupakan hal yang perlu diperhatikan oleh penyelenggara pelayanan publik. Sarana fisik gedung merupakan wadah organisasi dalam menjalankan pelayanan publik kepada masyarakat. Sarana fisik gedung juga harus didukung oleh sarana penunjang seperti sarana parkir yang mencukupi. Dan sarana ibadah untuk pengguna layanan yang beragama muslim. Berdasarkan dari hasil observasi dilapangan kondisi gedung kantor BPPT Kota Bandung terasa nyaman. Kondisi ruangan pelayanan perizinan

\footnotetext{
${ }^{13}$ Peraturan Menteri Dalam Negeri Nomor 20 Tahun 2008

${ }^{14}$ Peraturan Pemerintah No. 8 Tahun 2003 tentang Pedoman Organisasi Perangkat Daerah

${ }^{15}$ Peramesti, Ni Putu Depi Yulia. (2017) Penerapan Prinsip-Prinsip Good Environmental Governance dalam Pengelolaan Ruang Terbuka Hijau Di Kota Administrasi Jakarta Selatan. Dalam Jurnal MP (Manajemen Pemerintahan) : Vol.4, No.1 - Juni 2017 diakses dari http://ejournal.ipdn.ac.id/JMP/issue/view/52
} 
terasa sejuk. Ditambah adanya tanaman hias didalam ruangan, membuat suasana ruangan menjadi lebih segar. Gedung Badan Pelayanan Perizinan Terpadu (BPPT) Kota Bandung merupakan gedung bersama dengan Dinas Tata Kota dan Cipta Karya (DISTRACIP) Kota Bandung. Dimana kantor BPPT Kota Bandung berada di lantai 1, dan kantor DISTARCIP Kota Bandung berada di lantai 2. Adapun fasilitas penunjang pelayanan perizinan di BPPT Kota Bandung terdiri dari 1 buah masjid dan lahan parkir kendaraan. Kantor BPPT Kota Bandung berada dalam satu kompleks dengan dinas teknis, khususnya perizinan IMB seperti DISTARCIP Kota Bandung dan Dinas Bina Marga Kota Bandung. Sehingga dapat memudahkan koordinasi dalam pelayanan perizinan IMB.

Untuk menjaga dan memerlihara kebersihan, BPPT Kota Bandung telah meanggarkan alokasi dana kebersihan sebesar Rp.267.825.000,0016. Sejak tahun 2012, BPPT Kota Bandung menganggarkan dana untuk penyediaan jasa kebersihan kantor. Kebersihan merupakan syarat mutlak dalam menjalankan pelayanan publik kepada masyarakat. Masyarakat akan nyaman apabila penyelenggara pelayanan publik dapat memberikan fasilitas fisik yang bersih. Didalam pengertiannya, kebersihan adalah keadaan bebas dari kotoran, termasuk diantaranya debu, sampah, dan bau ${ }^{17}$.

Kecukupan ruangan pelayanan sangat diperlukan dalam menunjang kelancaran pelayanan publik. Setiap ruangan memiliki fungsinya masingmasing. BPPT Kota Bandung memiliki dari 28 ruangan yang terdiri dari ${ }^{18}$ :

\begin{tabular}{|l|l|l|l|}
\hline No & Nama Ruangan & No & Nama Ruangan \\
\hline 1 & $\begin{array}{l}\text { Ruang Hall dan Ruang } \\
\text { Tunggu }\end{array}$ & 16 & $\begin{array}{l}\text { Sub Bagian Pengolahan } \\
\text { Data Non Usaha }\end{array}$ \\
\hline 2 & Bank BJB & 17 & Kabid Non Usaha \\
\hline 3 & BPR & 18 & Kabid Usaha \\
\hline 4 & $\begin{array}{l}\text { Ruang Loket Informasi dan } \\
\text { Pengaduan }\end{array}$ & 19 & $\begin{array}{l}\text { Sub Bagian Pengolahan } \\
\text { Data Usaha }\end{array}$ \\
\hline 5 & Ruang Tunggu & 20 & $\begin{array}{l}\text { Arsip \& Pengoahan Data } \\
\text { Usaha }\end{array}$ \\
\hline 6 & Ruang Tunggu VIP & 21 & Kepala Badan \\
\hline 7 & $\begin{array}{l}\text { Ruang Lokat Pelayanan } \\
\text { Non Usaha }\end{array}$ & 22 & Staf Tata Usaha \\
\hline 8 & $\begin{array}{l}\text { Loket Pelayanan Usaha } \\
\text { Kubegawaian Keuangan \& }\end{array}$ \\
\hline
\end{tabular}

\footnotetext{
${ }^{16}$ Laporan Akuntabilitas Kinerja Intansi Pemerintah (LAKIP) BPPT Tahun 2012 hal 7

${ }^{17}$ http://id.wikipedia.org/wiki/Kebersihan

${ }^{18}$ Company Profile BPMPPT Kota Bandung
} 


\begin{tabular}{|l|l|l|l|}
\hline 9 & $\begin{array}{l}\text { Sub Bagian Pelayanan Non } \\
\text { Usaha }\end{array}$ & 24 & Sekretaris Badan \\
\hline 10 & $\begin{array}{l}\text { Sub Bagian Pelayanan } \\
\text { Usaha }\end{array}$ & 25 & Penomoran \\
\hline 11 & $\begin{array}{l}\text { Sub Bagian Informasi dan } \\
\text { Pengaduan }\end{array}$ & 26 & Ruang Rapat \\
\hline 12 & Verivikasi & 27 & Fungsional \\
\hline 13 & Tim Teknis & 28 & Area Service \\
\hline 14 & Ruang Briefing Pengolahan Data & $\begin{array}{l}\text { Ruang Pan } \\
\text { Non Usaha }\end{array}$ \\
\hline
\end{tabular}

Sumber : Company Profile BPMPPT Kota Bandung

Didalam kualitas pelayanan, ketersedian perlengkapan peralatan merupakan sarana pendukung dalam rangka memenuhi kebutuhan pelanggan secara optimal dan memenuhi harapan masyarakat. BPPT Kota Bandung menyediakan sarana E-Kiosk berbasis website sebagai sarana penunjang transparansi pelayanan yang dilengkapai dengan scan barcode. ${ }^{19}$ BPPT Kota Bandung menyediakan monitor khusus berupa layar sentuh (touchscreen) untuk membantu masyarakat dalam mempermudah akses layanan informasi, mulai dari persyaratan dan prosedur perizinan sampai disposisi berkas pengajuan IMB. Masyarakat dapat melakukan pengecekan disposisi berkas pengajuan melalui scan barcode pada nomor regritrasi pada formulir pendafataran. Dengan menggunakan layanan E-Kiosk di BPPT Kota Bandung, masyarakat dapat dengan mudah memantau disposisi berkas dokumen pengajuan IMB.

Kualitas pelayanan tidak hanya melakukan proses administrasi saja, tetapi juga perlu memperhatikan penampilan. Hal ini dikarenakan petugas layanan merupakan front office yang menjadi cerminan dari sebuah kualitas pelayanan, karena berhadapan langsung dengan masyarakat. Untuk membangun image atau persepsi masyarakat mengenai pelayanan perizinan, BPPT Kota Bandung menyediakan seragam tersendiri yang berbeda dengan SKPD lainnya. Seragam petugas layanan disediakan untuk memberikan citra positif dan mendekatkan dengan masyarakat sebagai pengguna layanan. Seragam tersebut didesain seperti karyawan kantoran pada umumnya, seperti menggunakan celana bahan, kemeja lengan panjang dan dasi untuk pria, dan blazer pada wanita. Khusus pada hari tertentu petugas layanan menggunakan batik.

Ketersediaan dan pengguna formulir layanan di BPPT Kota Bandung lebih mudah. Walaupun masih dirasakan sulit oleh beberapa responden. Untuk mempermudah layanan perizinan di BPPT Kota Bandung yang meliputi syarat dan prosedur layanan perizinan, BPPT Kota Bandung membagi bidang

${ }^{19}$ http://49.236.220.101/e-kiosk/ diakses pada tanggal 30/04/20152015 
pelayanan perizinan kedalam 4 bidang, yaitu, Bidang I, Bidang II, Bidang III, dan Bidang IV. Masing-masing bidang melayani beberapa pelayanan perizinan. Masing-masing perizinan memiliki kententuan persyaratan yang harus dipenuhi oleh para pemohon izin. Adapun Izin Mendirikan Bangunan (IMB) masuk kedalam Bidang II bersama Izin Lokasi, dan Izin Peruntukan Penggunaan Tanah.

Dalam mewujudkan tata kelola pemerintahan yang baik (good governance) dapat dilihat dari kualitas pelayanan. Kualitas pelayanan dapat dilihat dari bukti fisik (tangible) yang meliputi kenyamanan fisik gedung, kerapihan dan kebersihan ruangan pelayanan, kecukupan ruangan pelayanan, kelengkapan peralatan pelayanan, penampilan petugas layanan, sikap para petugas layanan, dan ketersediaan pengisian dan pengguna formulir layanan mudah. Ketujuh indikator tangible tersebut berdampak langsung kepada kualitas pelayanan yang diberikan kepada masyarakat. Sehingga dapat dikatakan dimensi tangible sangat mempengaruhi kualitas pelayanan.

\section{Dimensi Reliability (Kehandalan)}

Didalam menjalankan penyelenggaraan pelayanan publik perlu memiliki standar pelayanan yang baku. Standar pelayanan terpadu satu pintu di BPPT Kota Bandung mengacu kepada Peraturan Walikota Bandung Nomor 300 Tahun 2013 tentang Tugas Pokok, Fungsi, Uraian Tugas dan Tata Kerja Badan Pelayanan Perijinan Terpadu Kota Bandung untuk untuk pelaksanaan tugas. Sedangkan untuk pendelegasian wewenang pendatanganan dan penerbitan izin diserahkan kepada ketua BPPT Kota Bandung sesuai Keputusan Walikota Bandung Nomor : 503/Kep. 1172-Bag. ORPAD/2013 ${ }^{20}$.

BPPT Kota Bandung memiliki wewenang tertingi dalam menerbitkan perizinan. BPPT Kota Bandung dapat memberikan izin sesuai dengan ketentuan Peraturan Walikota Bandung Nomor 1171 Tahun 2013 pasal 4 dan Keputusan Walikota Bandung Nomor : 503/Kep. 1172-Bag. ORPAD/2013 diktum kedua. Secara kelembagaan, BPPT Kota Bandung juga melibatkan tim teknis dalam melakukan verivikasi perizinan. Untuk kelancaran koordinasi pelayanan perizinan, struktur BPPT Kota Bandung mengacu kepada Peraturan Menteri Dalam Negeri Nomor 20 Tahun 2008.

Didalam pelaksanaannya, BPPT Kota Bandung melakukan berkoordinasi dengan tim teknis yang menangani perizinan terkait. Dalam hal ini tim teknis IMB adalah DISTARCIP Kota Bandung. DISTRACIP Kota Bandung merupakan dinas yang memiliki wewenang didalam perizinan bangunan di Kota Bandung. Hal ini sesuai dengan Peraturan Menteri Dalam Negeri Nomor 20 Tahun 2008 pasal 10 ayat $2^{21}$. DISTARCIP sebagai tim teknis yang melakukan verivikasi

\footnotetext{
${ }^{20}$ Keputusan Walikota Bandung Nomor : 503/Kep. 1172-Bag. ORPAD/2013 tentang Pendelegasian Sebagian Wewenang Pendantanganan Perizinan Dari Walikota Bandung Kepada Badan Pelayanan Perizinan Terpadu Kota Bandung.

${ }^{21}$ Peraturan Menteri Dalam Negeri Nomor 20 Tahun 2008 tentang Pedoman Organisasi dan TataKerja Unit Pelayanan Perijinan Terpadu Di Daerah.
} 
persyaratan administrasi IMB sesuai dengan Peraturan Menteri Pekerjaan Umum Nomor 29/PRT/M/2006 tentang Pedoman Persyaratan Teknis Izin Mendirikan Bangunan Gedung 22.

Adapun tahapan yang harus dilalui oleh pemohon dalam memperoleh IMB di BPPT Kota Bandung adalah sebagai berikut :

1. Pemohon mencari informasi mengenai perizinan IMB di loket informasi.

2. Mengisi formulir dan melengkapi persyaratan.

3. Membuat Keterangan Rencana Kota (KRK) di DISTARCIP Kota Bandung.

4. Melakukan pendaftaran di BPPT Kota Bandung melalui loket pendaftaran. Setelah lengkap mendapatkan nomor resi.

5. Setelah berkas lengkap dan mendapatkan nomor resi, berkas persyartan administrasi masuk kedalam pengolahan dan penerbitan selama satu hari kerja.

6. Kemudian berkas persyaratan diserahkan kepada DISTARCIP untuk dilakukan pemerikasaan lapangan maksimal selama 7 hari kerja.

7. Bila sudah sesuai berkas diserahkan kembali ke BPPT Kota Bandung untuk dilakukan pencetakan izin dan perhitungan SKRD selama satu hari kerja.

8. Penandatangan berkas oleh kepada BPPT Kota Bandung selama satu hari kerja.

9. Dilakukan penomoran \& pengarsipan oleh secretariat badan selama satu hari kerja.

10. Penyerahan berkas izin dan SKRD (Surat Keterangan Restribusi Daerah) kepada pemohon

11. Melakukan pembayaran melalui loket pembayaran di Bank.

12. Menyerahkan bukti pembayaran di loket pengambilan berkas.

13. Menerima dokumen Izin Mendirikan Bangunan dan Papan Izin Proyek.

Pelayanan perizinan IMB di BPPT Kota Bandung adalah 19-60 hari kerja. Namun pada kenyataannya banyak pengajuan IMB yang tidak sesuai jadwal. Berdasarkan hasil observasi keterlambatan pengeluaran izin IMB dikarenakan banyaknya persyaratan yang tidak lengkap. Salah satu yang menjadi kendala adalah masalah site plan. Masalah site plan sering menjadi alasan mengapa dokumen IMB belum dapat dikeluarkan. Banyak masyarakat yang belum memahami pembuatan site plan. Bagi masyarakat yang tidak memahami pembuatan site plan biasanya meminta bantuan pada pihak ketiga atau konsultan, namun dengan biaya yang cukup mahal. Selain itu gambar site plan juga harus disesuaikan dengan rencana tata ruang kota.

\footnotetext{
${ }^{22}$ Peraturan Menteri Pekerjaan Umum Nomor 29/PRT/M/2006 tentang Pedoman Persyaratan Teknis Izin Mendirikan Bangunan Gedung dalam Standar Operasional Prosedur (SOP) Verivikasi Dokumen Teknis IMB Tahun 2011 hal 12
} 
Pada tahun 2014, jumlah permohonan IMB di BPPT Kota Bandung mencapai 4520 berkas. Dari 4520 berkas, 3773 berkas merupakan pengajuan IMB rumah tinggal. Berkas tersebut kemudian dilakukan verivikasi data untuk melihat kebasahan data. Data-data tersebut diverivikasi oleh tim teknis untuk dinilai apakah permohonan IMB ini layak untuk diterbitkan atau tidak. Tim teknis akan melihat bangunan tersebut apakah sudah sesuai dengan ketentuan yang berlaku atau tidak. Hal ini yang dilakukan oleh DISTARCIP Kota Bandung dan Dinas PU Kota Cimahi.Dari hasil penelitian yang telah dilakukan, kecepatan petugas layanan dalam menangani proses pengajuan IMB dipengaruhi adanya persyaratan yang belum dilengkapi oleh para pemohon. Keterlambatan di BPPT Kota Bandung umumnya disebabkan berkas layanan yang belum lengkap.

Berdasarkan hasil penelitian di lapangan, jadwal pelayanan di BPPT Kota Bandung dan KPPT Kota Cimahi sama-sama dimulai dari pukul 08:00 WIB hingga pukul 15:00 WIB. Sedangkan waktu istirahat di BPPT Kota Bandung dimulai dari pukul 12:00 WIB hingga pukul 13:30 WIB.

Dalam memenuhi harapan masyarakat, pelayanan perizinan yang diberikan BPPT Kota Bandung kepada masyarakat perlu diberi kemudahan. Kemudahan layanan meliputi penyediaan sarana fasilitas pendukung, ketersediaan petugas layanan yang siap membantu. BPPT Kota Bandung dalam memenuhi harapan masyarakat, memberikan fasilitas pendukung seperti, layanan E-Kiosk melalui layar sentuh (touchscreen), website BPPT Kota Bandung yang dapat diakses kapan saja dan dimana saja, dan petugas layanan yang siap membantu masyarakat.

Didalam penelitian ini, reliability atau kehandalan sangat diperlukan didalam pelayanan perizinan. Realiability merupakan suatu kemampuan penyelenggara pelayanan publik dalam memberikan pelayanan yang memuaskan dan sesuai dengan janji yang telah diberikan. Jadi baik buruknya kualitas pelayanan perizinan dapat dilihat dari dimensi reliability.

\section{Dimensi Responsiveness (Daya Tangkap)}

Dimensi responsiveness merupakan dimensi yang melihat bagaimana pelayanan publik dapat merespon apa yang dialami oleh pelanggan. Dalam menangani keluhan pelanggan, BPPT Kota Bandung menyediakan loket layanan pengaduan. Disini penguna layanan BPPT Kota Bandung dapat memberikan keluhan-keluhannya terkait pelayanan IMB. Berdasarkan hasil penelitian pengguna layanan banyak yang mengeluhkan lamanya waktu pembuatan IMB, dan banyaknya persyaratan yang belum dipahami oleh pemohon. Setidaknya dengan adanya loket layanan pengaduan, keluhan-keluhan pelanggan dapat ditampung untuk ditindak lanjuti.

Didalam penyelenggara pelayanan publik memang diperlukan layanan pengaduan untuk menangani keluhan pelanggan. Intansi yang menyelenggara pelayanan publik perlu menyediakan tempat khusus untuk melayani keluhan pelanggan. Tujuannya untuk mempermudah koordinasi dengan pihak terkait 
dan tidak menggangu aktivitas bagian pelayanan yang lain. BPPT Kota Bandung menyediakan layanan pengaduan agar tidak menggangu petugas layanan di bidang I, bidang II, bidang III, dan bidang IV. Jadi petugas layanan dapat lebih berkonsentrasi dalam menlayani pengguna layanan. Dalam menanggapi keluhan pelanggan, ketepatan dan kecepatan petugas layanan dan sikap keramahan dan kesopanan harus berjalan bersamaan. Menanggapi keluhan pelanggan, tentunya petugas layanan harus memperhatikan latar belakang pelanggan atau masyarakat.

Penyelenggara pelayanan publik harus menyediakan sarana dan prasarana kerja, peralatan kerja, dan sarana pendukung lainnya termasuk menyediakan sarana teknologi informasi. Petugas layanan sangat mampu dalam memberikan pelayanan secara menyeluruh kepada pelanggan.

Kemudahan akses disini adalah kemudahan pelanggan dalam memperoleh akses informasi. Untuk mempermudah layanan informasi kepada masyarakat, secara umum BPPT Kota Bandung menyediakan layanan akses informasi melalui website, $x$-banner, leaflet dan pamphlet. BPPT Kota Bandung menggunakan sosial media utuk memberikan layanan informasi yang dibutuhkan oleh masyarakat seperti jejaring sosial twitter. Untuk mengetahui perkembangan disposisi proses pembuatan IMB, masyarakat juga dapat melakukan monitoring dilaman website BPPT Kota Bandung. Masyarakat dapat mengetahui disposisi berkas dokumen pengajuan pada laman website dengan memasukan nomor resi pendaftaran. Kemudahan pelanggan dalam memperoleh akses informasi pelayanan pada saat ini sangat dipengaruhi oleh perkembangan teknologi informasi. Teknologi informasi sangat diperlukan dalam rangka mewujudkan good governance didalam pelayanan pubik.

Kemampuan petugas layanan dalam memberikan pelayanan secara menyeluruh kepada pelanggan, merupakan tolak ukur dari kualitas pelayanan. Hal ini dikarenakan, untuk menghindari kesenjangan antara persepsi masyarakat dengan penyelenggara pelayanan perizinan. Oleh karena itu petugas layanan harus mampun memberikan pelayanan secara menyeluruh. Penggunaan teknologi informasi juga penting untuk membantu petugas layanan dalam memberikan pelayanan perizinan secara menyeluruh. Selain itu, petugas layanan juga perlu memperhatikan perilaku konsumen (consumen behavior).

Untuk menghindari terjadinya kesalahapahaman (miscommunication) antara petugas layanan dan pengguna layanan perizinan. BPPT Kota Bandung menyediakan kotak saran terhadap pelayanan perizinan yang diterima oleh masyarakat. Selain itu BPPT Kota Bandung juga melakukan survey kepuasan pelanggan. Tujuannya untuk mengetahui sudah sejauh mana kepuasan masyarakat terhadap pelayanan yang diberikan oleh BPPT Kota Bandung. Dengan adanya survey kepuasan tersebut, masyarakat dapat dengan nyaman memberikan pendapat terhadap kualitas pelayanan yang diberikan. Survye kepuasan ini sangat penting untuk memperoleh masukan dari pengguna layanan. Karena survey kepuasan pelanggan ini bagian dari standar pelayanan 
publik. Sarana survey kepuasan menggunakan sarana sistem teknologi informasi. Dimana sarana survey kepuasan pelanggan menggunakan pendekatan teknologi. Dimana perangkat (hardware) survey kepuasan pelanggan terdiri dari layar monitor LED atau layar sentuh dan jaringan internet. Sehingga survey kepuasan pelanggan terintegrasi secara online. Selain itu BPPT Kota Bandung menggunakan aplikasi software khusus untuk survey kepuasan pelanggan. Dimana aplikasi tersebut berupa pertanyaan mengenai pengalaman pengguna layanan dalam mengikuti proses pembuatan perizinan IMB yang bekerja secara otomatis. Pengguna layanan cukup memberikan jawaban pada pilihan jawaban yang telah disediakan dengan menggunakan layar sentuh. Sehingga pengguna layanan dapat secara mudah dalam mengikuti survey kepuasan pelanggan.

\section{Dimensi Assurance (Jaminan)}

Didalam kualitas pelayanan, kesesuaian biaya dapat dijadikan tolak ukur. Sebagai penyelenggara pelayanan publik, BPPT Kota Bandung dituntut untuk memurahkan biaya administrasi pelayanan semuarah mungkin bila perlu gratis. Selain itu perizinan itu pada dasarnya merupakan legalitas yang dimiliki pemohon agar segala sesuatunya berjalan tertib dan tidak terjadi pelanggaran hukum. BPPT Kota Bandung sudah menetapkan tarif biaya perizinan sesuai dengan peraturan yang berlaku. Besaran biaya tarif IMB di BPPT Kota Bandung mengacu kepada Peraturan Daerah Kota Bandung Nomor 12 Tahun 2011 tentang Penyelenggaraan Restribusi Izin Mendirikan Bangunan dan Restribusi Penggantain Biaya Cetak Peta ${ }^{23}$.

Keberadaan pegawai didalam pelayanan publik sangat penting. Keberadaan pegawai salah satu unsur pengerak dari penyelenggaraan pelayanan publik. Kualitas pelayanan dapat dilihat dari keberadaan pegawai. BPPT Kota Bandung menempatkan para pegawai atau petugas layanan diposisi paling depan sebagai frontliner dan costumer service. Mereka ditempatkan di posisinya masing-masing untuk melayani kebutuhan masyarakat, mulai dari pendaftaran perizinan hingga layanan pengaduan.

Keakuratan data didalam pelayanan perizinan seperti IMB, sangat penting. Mengingat keberadaan IMB merupakan legalitas didalam mendirikan bangunan. IMB tidak hanya digunakan untuk rumah tinggal saja, tetapi juga untuk kepentingan lain seperti, kantor, toko, rumah tinggal toko, rumah tinggal kantor, dan lainnya. Apalagi IMB merupakan salah satu persyaratan dalam memperoleh izin yang lain, seperti Surat Izin Usaha Perdagangan (SIUP). Oleh sebab itu keakuratan data IMB harus diperhatikan oleh pengguna layanan. Dikhawatirkan legalitas dari IMB tersebut adalah palsu.

\footnotetext{
${ }^{23}$ Peraturan Daerah Kota Bandung Nomor 12 Tahun 2011 tentang Penyelenggaraan Restribusi Izin Mendirikan Bangunan dan Restribusi Penggantain Biaya Cetak Peta
} 
Kecepatan data juga harus dimbangi dengan kemajuan teknologi informasi. Karena dengan menggunakan teknologi informasi informasi yang disampaikan kepada pelanggan akan cepat tersampaikan. Mengingat sumber utama dari informasi adalah data. Dimana data sebagai bahan mentah yang diolah menjadi sebuah informasi. Data-data tersebut dapat berupa persyaratan perizinan yang diolah menjadi dokumen IMB. BPPT Kota Bandung menyediakan fasilitas layanan E-Kiosk dan website untuk mempercepat penyampaian informasi kepada pengguna layanan. Kecepatan data juga harus ditunjang oleh faktor manusia. Dimana didalam penanganan data, petugas layanan BPPT Kota Bandung dan KPPT Kota Cimahi melakukan pemerikasaan (verifying), perbandingan (comparing), pemilihan (sorting), peringkasan (extracting), dan penggunaan (manipulating). Jadi diperlukan sarana teknologi informasi yang memadai didalam melakukan pengelolaan data.

Kebenaran data harus ditunjang berdasarkan fakta dan angka dari berbagai sumber yang terbagi kedalam data kuantitatif dan data kualitatif. Secara kuantitatif, misalnya besaran tarif IMB yang harus dikeluarakan berdasarkan jenis bangunan. Sedangkan kebenaran data secara kualitatif merupakan data yang digolongkan/dikelompokan berdasarkan kategori tertentu, dan berhubungan dengan sifat tertentu. Misalanya pengelompokan data IMB berdasarkan jenis kegunaan bangunan. Kebenaran data juga harus ditunjang dari hasil pengamatan lapangan. Petugas layanan BPPT Kota Bandung melakukan pengamatan dilapangan. Petugas layanan melakukan pengamatan dengan cara melaukan pengecekan kondisi fisik bangunan, apakah bangunan tersebut sudah sesuai dengan yang diajukan oleh pemohon atau tidak.

Ketepatan data yang dimaksud adalah ketelitian. Ketelitian yang dimaksud adalah ketelitian pegawai dalam memverifikasi berkas dokumen layanan perizinan IMB. Berdasarkan dari pengamatan dilapangan telah ditemukan perbedaan sumber informasi persyaratan IMB di BPPT Kota Bandung. Berdasarkan hasil pengamatan, informasi layanan di website dan difamflet terdapat perbedaan. Sehingga meminggungkan masyarakat dalam mengumpulan berkas persyaratan IMB. Akibatnya ada beberapa berkas dokumen persyaratan IMB yang tidak sesuai akibat ketidakjelasan informasi pelayanan.

Didalam dimensi assurance ini ada beberapa indikator yang perlu diperhatikan yaitu, keseusian biaya layanan dengan prakteknya, keberadaan pegawai saat melayanai, keakuaratan data, kecepatan data, kebenaran data, dan ketepatan data. Tujuannya untuk memberikan jaminan kepada pengguna layanan didalam penyelenggaraan pelayanan publik. Jaminan yang diperoleh minimal pengguna layanan dapat memperoleh sumber informasi yang jelas. Selain itu besaran biaya yang dikeluarkan minimal sesuai dengan pelayanan yang diterima oleh pengguna layanan. 


\section{Dimensi Emphaty}

Salah satu wujud dari kualitas pelayanan yang baik adalah adanya perhatian individu kepada pengguna layanan. Perhatian individu yang diberikan kepada pengguna layanan oleh petugas layanan. Petugas layanan dapat memberikan bantuan atau kebutuhan yang diperlukan oleh pengguna layanan selama proses pembuatan IMB dari awal hingga selesai. Perhatian individu dapat dikatakan seabagi cerminan dari kualitas pelayanan itu sendiri. Kepedulian dan perhatian individual yang diberikan petugas layanan kepada pengguna layanan menunjukan sikap emapti petugas layanan yang tidak mendiskriminasikan pengguna layanan. Baik itu berdasarkan ras, agama, usia, jenis kelamin, dan lainnya. Sikap perhatian individual merupakan wujud dari rasa kepedulian BPPT Kota Bandung kepada masyarakat yang telah menggunakan layanan perizinan.

Petugas layanan perlu memahami bagaimana memperlakukan pengguna layanan dengan tetap. Misalnya membedakan sikap antara pengguna layanan kepada yang muda dan yang tua. Sikap petugas layanan merupakan cerminan dari kualitas pelayanan itu sendiri. Petugas layanan yang bertanggung jawab mampu menindaklanjuti keluhan-keluah pelanggan.

Kesungguhan petugas layanan dapat dilihat pada saat menindaklanjuti kebutuhan pengguna layanan perizinan. Petugas layanan juga harus memiliki jiwa low profile, maksudnya tidak angkuh dan memposisikan pengguna layanan sebagai raja yang harus diprioritaskan.

Petugas layanan perlu memahami kebutuhan pengguna layanan. Pengguna layanan tentunya memiliki kebutuhan yang berbeda-beda dari pengguna layanan lainnya. Sampai sejauh ini, petugas layanan BPPT Kota Bandung berusaha untuk memahami kebutuhan pengguna layanan. Walaupun petugas layanan terkadang belum sepenuhnya mampu dalam mamahami kebutuhan pengguna layanan. Hal ini juga dikarenakan terbatasnya jumlah petugas layanan.

Mendengarkan kebutuhan pengguna layanan, sama halnya memberikan respon kebutuhan pengguna layanan. Memberikan respon menunjukan adanya bentuk perhatian dan kepedulian kepada pengguna layanan. Mendengarkan keluhan pelanggan merupakan bentuk perhatian yang diberikan petugas layanan kepada pengguna layanan. Untuk memberikan pelayanan yang baik, petugas layanan perlu memberikan perhatain dalam bentuk mendengarkan keluhan pelanggan. Petugas layanan BPPT Kota Bandung lebih perhatian dibandingkan petugas layanan dalam menanggapi keluhan pelanggan.

\section{E. KESIMPULAN}

Berdasarkan hasil kesimpulan diatas, kualitas pelayanan Izin Mendirikan Bangunan (IMB) dapat dilihat dari lima dimensi kualitas pelayanan publik yang terdiri dari dimensi tangible, dimensi reliability, dimensi responsiveness, dimensi assurance, dan dimensi emphaty. Pada dimensi tangible, BPPT Kota Bandung perlu 
memberikan perhatian kenyamanan fisik gedung, kerapihan dan kebersihan ruangan, kecukupan ruangan pelayanan, kelengkapan peralatan pelayanan, penampilan petugas layanan, dan ketersediaan pengisian dan pengguna formulir layanan. Pada dimensi reliability, didalam pelayanan IMB perlu adanya standar pelayanan, ketepatan pemberian pelayanan, penyimpanan dokumen/berkas layanan, kecepatan petugas layanan dalam memberikan pelayanan, penerapan jadwal pelayanan perizinan tepat waktu dan teratur, dan adanya kemudahan dalam penyelesaian masalah pelayanan IMB. Pada dimensi responsiveness, pelayanan IMB dapat dilihat dari kemampuan petugas layanan dalam menanggapi keluhan pelanggan, kesegeraan tindakan petugas layanan dalam memberikan bantuan penyelesaian masalah, kemudahan pelanggan dalam memperoleh akses informasi pelayanan, adanya kemampuan petugas layanan dalam memberikan pelayanan secara menyeluruh kepada pelanggan, dan adanya kenyamanan pelanggan dalam mengeluarkan pendapat tentang kebutuhan kepada petugas layanan. Pada dimensi assurance, pelayanan IMB perlu memberikan jaminan kepada pengguna layanan baik itu, kesesuaian biaya, keberadaan pegawai, keakuratan data, kebenaran data, dan ketepatan data. Dan pada dimensi emphaty BPPT Kota Bandung juga perlu memberikan perhatian individu kepada pengguna layanan. Seperti petugas BPPT Kota Bandung dalam memberikan perhatian individual kepada pelanggan, memperlakukan pengguna layanan dengan bertanggung jawab, adanya kesungguhan dalam menghadapi kepentingan pengguna layanan, memahami kebutuhan pengguna layanan, mendengarkan kebutuhan pengguna layanan, mendengarkan dengan seksama keluhan-keluhan pelanggan, dan menindaklanjuti keluhan-keluhan pelanggan.

Dari kelima dimensi yang telah diatas dapat dikatakan telah diterapkan dalam pelayanan izin mendirikan bangunan (IMB) dan sudah mulai mendapatkan dukungan teknologi informasi. Teknologi informasi dapat menjadi faktor keberhasilan dalam membangun kualitas pelayanan IMB di Kota Bandung, khususnya pada dimenasi responsiveness agar dapat segera merespon kebutuhan pelanggan.

\section{F. DAFTAR PUSTAKA}

Parasuraman, A. Valerie A. Zeithmal, and Leonard L. Berry. 1985. A Conceptual Model of Service Quality and its Implications for Future Research. Dalam Journal of Marketing. Vol 49 (Fall 1985), 41-50.

Schiffman-Kanuk 1997. Consumer Behaviour. Fifth Edition. New York, USA. Prentice hall. International Edition. Inc.

Peramesti, Ni Putu Depi Yulia. (2017) Penerapan Prinsip-Prinsip Good 
Environmental Governance dalam Pengelolaan Ruang Terbuka Hijau Di Kota Administrasi Jakarta Selatan. Dalam Jurnal MP (Manajemen Pemerintahan) : Vol.4, No.1 - Juni 2017 diakses dari http://ejournal.ipdn.ac.id/JMP/issue/view/52

\section{DISERTASI}

Areros, William Agustinus. 2012. Implementasi Kebijakan Pemberian Izin Mendirikan Bangunan oleh Badan Pelayanan Perizinan Terpadu Kota Bandung: Universitas Padjadjaran.

\section{PERATURAN PERUNDANG-UNDANGAN}

Keputusan Walikota Bandung Nomor : 503/Kep. 1172-Bag. ORPAD/2013 tentang

Pendelegasian Sebagian Wewenang Pendantanganan Perizinan Dari Walikota Bandung Kepada Badan Pelayanan Perizinan Terpadu Kota Bandung.

Peraturan Pemerintah No. 8 Tahun 2003 tentang Pedoman Organisasi Perangkat Daerah

Peraturan Menteri Dalam Negeri Nomor 24 Tahun 2006 Tentang Pedoman Penyelenggaraan Pelayanan Terpadu Satu Pintu.

Peraturan Menteri Pekerjaan Umum Nomor 29/PRT/M/2006 tentang Pedoman Persyaratan Teknis Izin Mendirikan Bangunan Gedung dalam Standar Operasional Prosedur (SOP) Verivikasi Dokumen Teknis IMB Tahun 2011 hal 12

Peraturan Menteri Dalam Negeri Nomor 20 Tahun 2008 tentang Pedomen Organisasi dan Tata Kerja Unit Pelayanan Perizinan Terpadu Di Daerah.

Peraturan Daerah Kota Bandung Nomor 12 Tahun 2011 tentang Penyelenggaraan Restribusi Izin Mendirikan Bangunan dan Restribusi Penggantain Biaya Cetak Peta

Walikota Bandung Nomor 1171 Tahun 2013 tentang Prosedur Penyelenggaraan Pelayanan Perizinan Terpadu Satu Pintu Paragraf 9A Badan Pelayanan Perijinan Terpadu Pasal 12A. 
Undang-Undang No. 25 Tahun 2007 tentang Penanaman Modal

\section{SUMBER LAINNYA}

Hasil Observasi Peneliti pada tanggal 13 Agustus - 21 Januari 2015 di Pemerintah Kota Bandung.

Hasil Olahan Penelitian Tahun 2015

http:/ / www.boss.or.id/index.php?option=com_content\&view=article\&id=76\&I temid=99 diakses pada tanggal 30/04/2015

http://49.236.220.101/e-kiosk/ diakses pada tanggal 30/04/20152015

http://bppt.bandung.go.id/web/index.php/pages/detail/43-formulir diakses $30 / 05 / 2015$ 